\section{PP-573 尿管結石患者の治療期間についての検} 討

\begin{abstract}
公立学校共済組合 関東中央病院 泌尿器科" 東京医 科歯科大学 大学院 尿路生殖機能学 (泌尿器科) ${ }^{2)}$ 尾関 全", 石坂 和博", 小林 秀一郎", 町田 竜也" 影山幸雄 ${ }^{2}$, 木原 和徳"

【目的]尿路結石思者の治㙩にかかる期間について検討した，[対象と方法] 対象住 2000 年 8 月 1 日から 2002 年 7 月 31 日までの 2 年間に, 関東中央 病院泌尿器科を受診した初診患者のうち, 尿管結石と診断された 407 例の 患者である. 男性 310 例，女性 97 例. 平均年齢 44.5 歲. 左 208 例, 右 197 例, 耐溉 2 例. 結石の最大径が $4 \mathrm{~mm}$ 以下が 107 例, $5 \mathrm{~mm}$ 以上 $10 \mathrm{~mm}$ 以下 が 168 例, $11 \mathrm{~mm}$ 以上 $20 \mathrm{~mm}$ 以下が 26 例, $21 \mathrm{~mm}$ 以上が 2 例, 大きさ不 明が 104 例である. 部位は U1 のみが 131 例, U2 のみが 18 例, U3 のみが 151 例，U1 とU3に認めるのが 1 例，部位不明のものが106例であった。 初診から排石を磼認した時点，または患者にとっての問题が解決したとし て観察を終了した時点までの期間を調査した! 結果了排石未確認の症例， 経過観察中に受診しなくなった症例，経過観察を他院に依頼した症例など 63 例は調査加除外した. $4 \mathrm{~mm}$ 以下で ESWL 施行 28 例の平均治療期間 は $10.9 \pm 9.8$ 日 $(\mathrm{m} \pm \mathrm{SD}) .4 \mathrm{~mm}$ 以下で ESWL非施行 53 例は $12.3 \pm 16.0$ 日. 5 10mm で, ESWL 施行 112 例は $15.9 \pm 15.8$ 日, ESWL 非施行 28 例は $22.0 \pm 28.3$ 日 ( $\mathrm{p}<0.05, \mathrm{t}$ 検定). 11 20mm で ESWL 施行 20 例は 24.6 士22.2日であった[考察]最大径 $10 \mathrm{~mm}$ 以下の尿管結石に ESWLを施行 した症例は非施行群に比べ問傿解決までの期間が短い㑯向であり，患者の QOLを考慮すると，積柾的にESWLを施行すべきと考えられた。
\end{abstract}

\section{PP-574 ESWL 後残石の成長に対する臨床的検} 討

\footnotetext{
稲城市立病院 泌尿器科" 東海大学東京病院 泌尿器 科 ${ }^{2)}$

松下 一男 ${ }^{2)}$, 松崎 章二", 松下一男 ${ }^{21}$, 長妻 克己 ${ }^{11}$

島 政則 ${ }^{21}$

【目的】ESWL 後研石片が残り、それが成長して再治療を必要とした 症例を経験する。今回 ESWL 後残石の成長について検討した。対象 と方法了ESWL施行 3 ヶ月以降、腎に残石を認めた患者を対象とし た。残石の成長はXPで確認した。残石成長の累積発生率は最終 ESWL 日を起点として、残石の成長が確認された日をエンドポイン トとし Kaplan-Meier 法で算出した。結果】観察期間は $2127 \pm 1648$ 日 (平均值士標準偏差值)で、対象者 229 名中 103 名に残石の成長が 見られた。残石成長の累皘発生率は 1 年 $0.04 、 2$ 年 $0.22 、 3$ 年 0.36 .4 年 0.48 .5 年 $0.54 、 7$ 年 $0.68 、 10$ 年 0.80 であった。残石が成長した 103 名を残石成長群、残石成長がなかった 126 名を非残石成長群と分類 した。初診時の平均年齢は残石成長群 48.0 歳、非残石成長群 52.7 瓷であった。結石の平均サイズは残石成長群 $14.4 \mathrm{~mm}$ 、非残石成長群 $11.1 \mathrm{~mm}$ であった。結石数の平均は残石成長群 2.3 個、非残石成長群 2.2 個であった。BMI は残石成長群 23.6、非残石成長群 22.6であっ た。残石成長群と非残石成長群では、高苳酸尿症が $45 \% 、 36 \%$ 、高 カルシウム尿症 37\%、23\%、低クエン酸尿症 30\%、39\%、低マグネ シウム尿症 $15 \%$ 、43\%に認められた。結論】ESWL 後残石の成長に は年䶕、結石サイズ、高カルシウム尿症、高葆酸尿症が関係していた。
}

\section{PP-575 2cm以上 $3 \mathrm{~cm}$ 末満の腎䊅石にD- Jstent 留置下のESWL は有効かつ安全 である。}

\author{
産業医科大学 泌尿器科学 \\ 佐藤 英樹, 西井 久枝, 寺戸三千和, 飯原 清隆 \\ 原田 修司, 赤坂 聡一郎, 山田 陽司, 藤本 直浩 \\ 高橋 康一, 松本 哲朗
}

【目的】AUA や EAU では $2 \mathrm{~cm}$ 以上の結石は PNL や PNL との併用療 法を钓めている。当科では $2 \mathrm{~cm}$ 以上 $3 \mathrm{~cm}$ 末满の結石(以下 A 群と略す) はD-Jstent を留置しESWLを行ってきたが、その成績を $2 \mathrm{~cm}$ 末満のも の（以下 B 群と略す）と比較検討した。対象と方法】当教室では 1998 年 3 月にシーメンス社製 Lithostar Multiline 導入し、2002.年 9 月ま でに153例の腎結石に对して ESWLを施行した。結石部位、治療回数、 衝撃波数、最大電圧、治療成績、合併症につき検討した。治療成績は残 石の無いものを完全破砕、4mm 以下の残石が存在するものを加えたも のは有効破砕とした。【結果】153 例の腎結石の内 A 群は 21 例(13.7\%)、 R2 4 例、R3 17 例。B 群は 132 例 (75.8\%)、R2 50 例、R3 82 例。平均治 療回数は A 群 1.81 回、B 群 1.38 回。平均衝撃波数は A 群が $4241.9 、 \mathrm{~B}$ 群は 4353.3。最大電圧はA 群 2.75、B 群は2.66。治療成績は $\mathrm{A}$ 群は完全 破砕 8 例 (38.1\%)、有効破砕 18 例 (85.7\%)。B 群は完全破砕 70 例 (53 $\%)$ 、有效破砕 122 例 $(92.4 \%)$ 。主な合併症は A 群に stone street 形成 5 例、腎血腎炎 2 例、腎周囲血腫 1 例。B 群では stone street 形成 3 例、 腎監炎 5 例、精巣上体炎 1 例であった。結論】 $2 \mathrm{~cm}$ 以上 $3 \mathrm{~cm}$ 末満の腎 結石に D-Jstent 留置下の ESWL は stone street 形成の頻度が高くなる ものの臨床的に問題となることは少なく、有効かつ安全であった。

\section{PP-576 小児症例における ESWLのエ夫}

\section{国立国際医療センター}

藤村 哲也, 野宮 明, 浜崎 公久, 浜本 敏明, 箩和田 滋 岸 洋一

緒言：現在 ESWL は広くおこなわれているが、小児にお ける症例は少ない。治療における工夫について検討した。 症例：2 歳、女览。身長 $56 \mathrm{~cm}$ 、体重 $11 \mathrm{~kg}$ 。在胎 40 週に左 水腎症指摘。1 歳時に尿路感染症。定期的経過観察にて右 腎結石指摘。加療目的にて入院。排泄性腎昷造影にて右腎 内腎桖の狭窄による水腎症、および狭窄部に $2 \mathrm{~cm}$ 大の腎 結石認め、左側は腎盖尿管移行部の狭窄、腎外腎昷の拡張 を認めた。全身麻酔にて右尿管ステント $(4.7 \mathrm{Fr}, 14 \mathrm{~cm})$ 留 置。その後、ESWL 施行。結石破砕装置はシーメンス社の Multiline。小児アダプターの上で仰卧位にて固定。本症例 は成人より極端に体の厚さがなく焦点が合わないため、 輸液のソフトバッグ $500 \mathrm{ml}$ を 2 重ねメンブレンの上に テープ固定した。成人腎結石では 4〜 5kv, 3000〜 4000shot で治療を行うが、2つのソフトバッグの計 4 枚のビニール による衝撃波の減衰を考慮し、5kv 2500shotの治療を 行った。結果：安全に行われ合併症は認めなかった。排石 もみられたが破砕は完全でなく再治療をおこなった。考 察：比較的稀な小児の ESWLにおける工夫を報告した。 通常 ESWL は外来通院で外来棟で行っているが、小览治 療に際して治療室に麻酔器、吸引設備などが必要である。 